\title{
Bovine milk fat globule membrane affects virulence expression in Escherichia coli 0157:H7
}

\author{
A. Tellez, ${ }^{\star} \dagger$ M. Corredig, ${ }^{\star}$ A. Guri, ${ }^{*}$ R. Zanabria, ${ }^{\star}$ M. W. Griffiths, ${ }^{*} \dagger$ and V. Delcenserie ${ }^{\star}+\ddagger^{1}$ \\ *Department of Food Science, and \\ †Canadian Research Institute for Food Safety, University of Guelph, Guelph, ON, N1G 2W1, Canada \\ ¥Food Sciences Department, Faculty of Veterinary Medicine, University of Liège, Sart-Tilman, B43b Liege, B-4000 Belgium
}

\begin{abstract}
The aim of this study was to examine the effect of the bovine milk fat globule membrane (MFGM) on the virulence of Escherichia coli O157:H7. The MFGM was extracted from raw or heat-treated milk, resulting in 2 preparations differing in protein composition. Both heated and raw MFGM exerted an inhibitory effect on Shiga toxin gene expression by E. coli O157:H7 (ratios of -7.69 and -5.96 , respectively). Interestingly, the effect was stronger with heated MFGM, with a larger decrease in expression of the virulence gene $f l i C$ (ratio of -9.43). The difference in effect observed between heated and raw MFGM could be explained by the difference in protein composition between the 2 preparations. These results show, for the first time, a specific effect of MFGM on expression of Shiga toxin genes as well as genes involved in the motility of E. coli O157:H7. This may offer a new approach to mitigate the adverse health effects caused by $E$. coli O157:H7 infections.
\end{abstract}

Key words: milk fat globule membrane, virulence, Escherichia coli O157:H7

\section{INTRODUCTION}

Escherichia coli O157:H7 was first recognized as a pathogen in 1982, and since then it has been associated with several outbreaks around the world (Paton and Paton, 1998; McClure, 2005). Enterohemorrhagic Escherichia coli O157:H7 (EHEC O157) is a member of the attaching and effacing $E$. coli group. It possesses virulence factors essential for adhesion of the pathogen to intestinal epithelial cells (attachment) and responsible for the destruction of the brush-border of microvilli (effacement; Paton and Paton, 1998; LeBlanc, 2003). Enterohemorrhagic E. coli O157 has a chromosomal pathogenicity island called the locus of enterocyte effacement (LEE). Shiga toxin-producing Escherichia

Received March 22, 2012

Accepted July 29, 2012.

${ }^{1}$ Corresponding author: veronique.delcenserie@ulg.ac.be coli (STEC) are important gastrointestinal pathogens of humans. Production of Shiga toxin (Stx) may cause local damage to blood vessels in the colon and result in bloody diarrhea (Paton and Paton, 1998). If sufficient Stx is absorbed into the circulation, vascular endothelial sites rich in toxin receptors are damaged, leading to impaired function. The kidneys and central nervous system are frequently affected sites and hemolytic uremic syndrome may develop (Proulx et al., 2001). Hemolytic uremic syndrome occurs due to the action of the 2 most important members of the Stx family: Stx1 and Stx2 (Griffin and Tauxe, 1991). The STEC can produce one or both types of Stx; however, Stx2 is associated with the most severe disease in humans (Wen et al., 2006). The mechanism of action of Stx2 is not completely understood but some studies indicate that the toxin induces a multifaceted host inflammatory response (Paton and Paton, 1998; Boerlin et al., 1999; Proulx et al., 2001).

The fat globules in milk in their native form are surrounded by a complex membrane composed of phospholipids and several bioactive components (Singh, 2006). This membrane is derived from the apical cell membrane of the mammary cell. The proteins present in the milk fat globule membrane (MFGM) differ from those present in milk and are associated with biological functions such as lipid delivery, modulation of lipase adsorption and activity in the digestive tract, hydrolysis of triacylglycerols and lipoprotein synthesis, cholesterol absorption, and defense mechanisms in the newborn (Kanno et al., 1991; Lopez, 2010). Milk fat globule membrane can be isolated from raw milk, butter serum, or buttermilk, the by-product obtained when cream is churned into butter (Corredig et al., 2003). The MFGM fraction has high emulsifying capacity, moisturizing properties, nutritional value, and health-promoting properties (Corredig et al., 2003; Heid and Keenan, 2005; Spitsberg, 2005; Singh, 2006; Sichien et al., 2009). The composition of the MFGM is markedly affected by heating, cooling, homogenization, evaporation, and spray drying (Singh, 2006). At temperatures above $60^{\circ} \mathrm{C}$, MFGM is modified because 
of its interaction with milk proteins, especially $\beta$-LG, inducing changes to solubility, iron content, and emulsifying properties (Sharma and Dalgleish, 1994; Corredig and Dalgleish, 1998).

Several health-promoting effects have been attributed to the components present in the MFGM, including anticancer, immune-stimulation, anticholesterolemic, and antimicrobial effects (Parodi, 1997; Page et al., 1998; Vissac et al., 2002; Martin et al., 2004). The MFGM glycoproteins also seem to play an important role in the prevention of pathogenic infections, and are able to act as specific bacterial and viral ligands in the stomach of newborns, thereby preventing attack of the intestinal mucosa by pathogens (Murgiano et al., 2009). Healing effects of defatted and non-defatted MFGM on Helicobacter pylori infection of the gastric mucosa in mice have also been observed; the results suggest that the protein fraction of MFGM plays a major role in the inhibition of $H$. pylori infection (Wang et al., 2001). LeBlanc (2003) has shown that MFGM hydrolysates exhibit antibacterial activity against E. coli O157:H7, although lower level responses were elicited upon incubation with Listeria monocytogenes, Salmonella Typhimurium, and Pseudomonas fluorescens. Pepsintreated MFGM fractions showed the greatest effect on $P$. fluorescens cultures and slightly slowed the proliferation rate of E. coli $\mathrm{O} 157: \mathrm{H} 7$ and L. monocytogenes. Recent reports indicate that the supramolecular structure and composition of the MFGM may play a major role in its bioactivity (Lopez, 2010).

To date, no research has examined the effect of MFGM on the virulence of E. coli O157:H7; therefore, the objective of this study was to explore the ability of MFGM to interfere with gene regulation responsible for the pathogenicity of EHEC O157:H7. Two different fractions of MFGM were prepared from raw and heattreated milk to investigate whether processing modifies this effect.

\section{MATERIALS AND METHODS}

\section{MFGM Preparation}

Raw milk was collected from the Elora Research Station (Guelph, ON, Canada) by using a sterile catheter inserted into the cow's udder to minimize contamination. A portion of the milk was then heated $\left(80^{\circ} \mathrm{C}\right.$ for $10 \mathrm{~min}$ ) in sterile glass containers in a thermostatically controlled water bath, and immediately cooled to about $20^{\circ} \mathrm{C}$ in an ice bath. Raw or heat-treated cream was produced by centrifugation at $4,800 \times g$ for $30 \mathrm{~min}$ at $4^{\circ} \mathrm{C}$ (model J2-21, Beckman Coulter, Mississauga, ON, Canada). Following centrifugation, the liquid serum was removed and the cream resuspended in
LPS-free water (1:10). Removal of the remaining serum components not attached to the MFGM was carried out by centrifugation using the same centrifugation parameters as above and washing the cream 2 additional times. Raw and heat-treated cream was then subjected to 2 freeze-thaw cycles from $-20^{\circ} \mathrm{C}$ to $37^{\circ} \mathrm{C}$. Sodium citrate ( $1 \%$ by vol) was added after the last thaw cycle at $37^{\circ} \mathrm{C}$. After destabilization of the fat globules by freeze-thawing, the MFGM extracts were collected in pyrogen-free containers by ultracentrifugation at 60,000 $\times g$ for $1 \mathrm{~h}$ (Optima LE-80K, Beckman Coulter) at $4^{\circ} \mathrm{C}$. The pelleted extracts were resuspended in 3 to $5 \mathrm{~mL}$ of Milli-Q (Millipore, Billerica, MA) LPS-free water, and freeze-dried.

The MFGM solutions were prepared using the freezedried materials by mixing a minimum of $10 \mathrm{mg}$ of MFGM with Milli-Q water (2:1 wt/vol) and analyzed for protein content using the DC Protein Assay Kit II (Pierce, Rockford, IL). Standard curves were generated with BSA.

\section{SDS-PAGE Electrophoresis}

The protein profile of the MFGM isolates was determined using SDS-PAGE under reducing conditions, as previously described (Corredig and Dalgleish, 1998). Briefly, freeze-dried samples were dissolved in buffer containing $60 \mathrm{~m} M$ Tris $\mathrm{HCl}, \mathrm{pH} 6.8,20 \%$ glycerol, $2 \%$ SDS, $0.25 \% \beta$-mercaptoethanol, and $0.01 \%$ bromophenol blue and heated at $95^{\circ} \mathrm{C}$ for $5 \mathrm{~min}$. Before loading, the samples were centrifuged at $6,000 \times g$ for 10 min using an Eppendorf centrifuge (Brinkmann Instruments, Westbury, NY). The protein was fixed and stained using a Coomassie Blue R-250 solution (Pierce), and bands were identified by comparing with molecular weight standards and literature reports. Three micrograms of protein was loaded in each lane.

\section{Effect of MFGM on E. coli Reporter Constructs}

Two reporter plasmid constructs: (LEE1) EHEC O157 LEE1::luxCDABE and (LEE2) EHEC O157 $L E E 2:: \operatorname{lu} x C D A B E$ were used to investigate whether the MFGM fractions played a role in the regulation of the chromosomal PAI identified as the LEE. The constructs were prepared as described in a previous article (Medellin-Peña et al., 2007). Constructs were grown for $18 \mathrm{~h}$ at $37^{\circ} \mathrm{C}$ in Luria-Bertani broth (LB; Becton Dickinson, Mississauga, ON, Canada) supplemented with $50 \mu \mathrm{g} / \mathrm{mL}$ of ampicillin. The resulting cell suspensions were diluted 1:100 in fresh medium with and without supplementation with MFGM. The MFGM was tested at 3 protein concentrations: 10,100 , and $1,000 \mu \mathrm{g} / \mathrm{mL}$. Two hundred microliters of each sample was distrib- 
uted in triplicate into wells of a sterile, opaque 96-well plate (Corning No. 3610, Fisher Scientific Canada, Ottawa, ON, Canada) and incubated at $37^{\circ} \mathrm{C}$. Luminescence and cell density were measured every hour with a Wallac 1420 Victor Multilabel Counter (Wallac, PerkinElmer Life Sciences Canada, Woodbridge, ON, Canada). Luminescence was measured as relative light units (RLU, counts/min).

\section{Effect of MFGM on Transcription of Virulence Genes of EHEC}

To study the effects of heat-treated milk fat fractions versus raw milk fat fractions on gene expression of a wild type E. coli $\mathrm{O} 157: \mathrm{H} 7$, we analyzed the expression of the genes ler (involved in attaching effacing lesions), $f l i C$ (necessary for motility), stx2B (encoding subunit B of Stx2), and luxS (involved in quorum sensing and AI-2 synthesis) by using reverse transcription-quantitative PCR (RT-qPCR).

$\boldsymbol{R N A}$ Extraction. Enterohemorrhagic E. coli O157:H7 strain 43894 was grown in LB medium alone (control) or in LB supplemented with $100 \mu \mathrm{L} / \mathrm{mL}$ of raw MFGM or heat-treated MFGM (treatments). After 4 and $6 \mathrm{~h}$ (mid-exponential phase), at an average optical density of 0.83 and 0.88 , respectively, $4-\mathrm{mL}$ samples were withdrawn and mixed with 1 equivalent volume of RNA Protect stabilization reagent (Qiagen, Mississauga, ON, Canada). Cells were collected after centrifugation at $5,000 \times g$ for $10 \mathrm{~min}$ in an Avanti J-20 XPI centrifuge (Beckman Coulter) at room temperature. Cells were lysed using reagents from the RNeasy Mini kit (Qiagen) and samples were stored overnight at $-80^{\circ} \mathrm{C}$ according to the manufacturer's instructions. On the following day, RNA was extracted using the same kit.

After RNA extraction, DNA contamination was eliminated from each sample using DNase I recombinant RNase-free (Roche Applied Science, Laval, QC, Canada). Briefly, $20 \mu \mathrm{L}$ of total RNA was incubated for 30 min at $37^{\circ} \mathrm{C}$ with $10 \mathrm{U}$ of DNase I, $10 \mathrm{U}$ of RNase inhibitor, and $5 \mu \mathrm{L}$ of incubation buffer in a total volume of $50 \mu \mathrm{L}$. The RNA was then purified using the clean-up kit (Qiagen, Montreal, QC, Canada) and solubilized in $30 \mu \mathrm{L}$ of molecular-grade water. The quantity of RNA present was determined by measuring the absorbance at $260 \mathrm{~nm}$ using a spectrophotometer (NanoDrop 1000, ThermoScientific, Wilmington, DE). The RNA quality was verified by measuring the ratio of the absorbance at $260 \mathrm{~nm} / 280 \mathrm{~nm}$ and by gel electrophoresis. The purified RNA was used immediately for RT-PCR using a cDNA high-capacity reverse transcription kit (Applied Biosystems Canada, Mississauga, ON, Canada). Briefly, $1 \mu \mathrm{g}$ of RNA was reverse transcribed with 0.8 $\mu \mathrm{L}$ of deoxyribonucleotide triphosphate (dNTP; 100 $\mathrm{m} M), 1 \mu \mathrm{L}$ of Multiscribe reverse transcriptase (50 U/ $\mu \mathrm{L}$, Applied Biosystems Canada), $2 \mu \mathrm{L}$ of $10 \times$ random hexamer primers, $2 \mu \mathrm{L}$ of $10 \times$ RT buffer in an adjusted total volume of $20 \mu \mathrm{L}$ using molecular-grade water. For each sample, a no-RT control was included to confirm the absence of contaminating DNA. Synthesis of cDNA was performed in a Mastercycler gradient thermocycler (Eppendorf, Mississauga, ON, Canada) with the following conditions: $25^{\circ} \mathrm{C}$ for $10 \mathrm{~min}, 37^{\circ} \mathrm{C}$ for $120 \mathrm{~min}, 85^{\circ} \mathrm{C}$ for $5 \mathrm{~min}$, and a cooling step to $4^{\circ} \mathrm{C}$. The cDNA was stored at $-20^{\circ} \mathrm{C}$.

$\boldsymbol{R T}-\boldsymbol{q P C R}$. Quantitative PCR amplification was performed using an ABI Prism 7900HT Sequence Detector (Applied Biosystems, Carlsbad, CA) using Power Sybr Green PCR master mix (Applied Biosystems) according to the manufacturer's instructions and with primers as previously published (Pfaffl, 2001; Rashid et al., 2006; Medellin-Peña et al., 2007). All the primers were checked to confirm their specificity for the tested genome sequences using GenBank (accession numbers: luxS: NC_011353; ler: NC_013008; fliC: NC_002655; stxB2: NC_000924; gnd: NC_002655; gst: NC_002655) and Clustal W2 (http://www.ebi.ac.uk/Tools/msa/ clustalw2/). The primers were synthesized by the Laboratory Service Division (University of Guelph, ON, Canada). Stock solutions of $40 \mathrm{~m} M$ were prepared and stored at $-20^{\circ} \mathrm{C}$. The sequences of the primers were as follows: gnd [forward (F): 5'GGTAATACCTTCTTCCAGGACACC; reverse (R): 5'TAGTGCGCCCTCCTCACC), gst (F: 5'CTTTGCCGTTAACCCTAAGGG; R: 5'GCTGCAATGTGCTCTAACCC), ler (F: 5'TTTCTTCTTCAGTGTCCTTCA; R: 5'TGCGGAGATTATTTATTATGA), stxB2 (F: 5'AGATGTTTATGGCGGTTTTA; R: 5'TTAAACTGCACTTCAGCAAA), luxS (F: 5'GATCATACCCGGATGGAAG; R: 5'AGAATGCTACGCGCAATATC) and fliC (F: 5'TACCATCGCAAAAGCAACTCC; R: 5'GTCGGCAACGTTAGTGATACC). The annealing temperature was determined experimentally $\left(54^{\circ} \mathrm{C}\right)$.

The PCR was performed in a total volume of $25 \mu \mathrm{L}$, which contained $12.5 \mu \mathrm{L}$ of Power Sybr Green PCR master mix, $0.5 \mu \mathrm{L}$ of forward primer $(800 \mathrm{pmol} / \mathrm{reac}-$ tion), $0.5 \mu \mathrm{L}$ of reverse primer $(800 \mathrm{pmol} /$ reaction $), 1$ $\mu \mathrm{L}$ of diluted $\mathrm{cDNA}$, and $10.5 \mu \mathrm{L}$ of molecular-grade water. Each PCR was performed in triplicate. The PCR conditions were as follows: denaturation program: $95^{\circ} \mathrm{C}$ for $10 \mathrm{~min}$; amplification and quantification repeated 40 times: $95^{\circ} \mathrm{C}$ for $30 \mathrm{~s}, 54^{\circ} \mathrm{C}$ for $30 \mathrm{~s}$, and $72^{\circ} \mathrm{C}$ for 30 $\mathrm{s}$; melting curve program: $60^{\circ} \mathrm{C}$ to $95^{\circ} \mathrm{C}$ with a heating rate of $0.1^{\circ} \mathrm{C} / \mathrm{s}$, and finally a cooling step to $40^{\circ} \mathrm{C}$. Each specific amplicon was verified by the presence of a single melting-temperature peak and a single band of expected size on a 1\% agarose gel after electrophoresis. 
Cycle threshold $(\mathbf{C t})$ values were determined with the Applied Biosystems software provided with the instrument. Two housekeeping genes (glutathione transferase, gst, and 6-phosphogluconate dehydrogenase, gnd) were tested. The transcript levels were normalized to the geometric average of expression of both housekeeping genes for each sample (Vandesompele et al., 2002). The relative changes in gene expression were calculated as described by Pfaffl (2001) using the formula: Ratio = (E target) delta $\mathrm{Ct}$ target (control - sample) / (E ref) delta Ct ref (control - sample), where $\mathrm{E}$ is the efficiency of the qPCR. The samples were analyzed in triplicate and the experiment was replicated 3 times.

\section{Statistical Analysis}

All results presented are means \pm standard deviation of the results of 3 independent trials between test and control groups. Student's $t$-test was used when necessary to assess the statistical significance of the differences between test and control groups, with a $P$-value of $\leq 0.05$ considered significant.

\section{RESULTS AND DISCUSSION}

\section{Characterization of the MFGM Isolates}

Freeze-dried fractions of MFGM were reconstituted at about $2 \mathrm{mg} / \mathrm{mL}$ and protein analysis was performed. Raw and heat-treated milk MFGM contained, respectively, $0.74 \pm 0.03$ and $0.56 \pm 0.07 \mathrm{mg} / \mathrm{mL}$. Sodium dodecyl sulfate-PAGE analysis was performed to determine the composition of the major polypeptide bands (data not shown). The untreated MFGM showed the presence of high-molecular-weight bands (>50 kDa) typical of the proteins from the MFGM (Kanno et al., 1991). Xanthine oxidase, butyrophilin, and PAS $6 / 7$ (lactadherin) were the major proteins identified, with molecular weights of approximately 145,67 , and $55 \mathrm{kDa}$, respectively. Because of the extensive washing procedure applied to the cream before the extraction, the major proteins derived from skim milk (caseins, $\beta-\mathrm{LG}$, and $\alpha-\mathrm{LA}$ ) were not found in the samples. On the other hand, it was clear that the heat-treated MFGM sample had bands that were more diffuse, and fewer MFGM-derived proteins were recovered in this sample. In addition, because of the extensive washing procedure applied to the cream, the largest protein aggregates obtained from heat treatment might have been released in the soluble phase.

In addition, some faint bands were found below the $37 \mathrm{kDa}$ region, possibly representing the guanosine triphosphate (GTP)-binding proteins (Ye et al., 2002). The gel clearly showed that heat treatment not only resulted in the thermal denaturation of the proteins, which decreased the solubility of the proteins (Corredig and Dalgleish, 1998), but also caused a change in the composition of the protein fraction in the MFGM extract obtained and an increase in the ratio of phospholipid to protein in the samples.

\section{Effect of MFGM on LEE Promoter Activity}

The MFGM extracts derived from raw and heattreated milk were tested at 3 protein concentrations against the 2 EHEC O157 reporter plasmid constructs, LEE1 and LEE2, and luminescence was quantified. Neither raw nor heat-treated MFGM downregulated gene expression for the LEE2 reporter (results not shown). However, for LEE1, the heat-treated MFGM significantly $(P \leq 0.05)$ downregulated the reporter gene expression of LEE1 at all protein concentrations tested (Figure 1), whereas the raw MFGM fraction did not suppress gene promoter activity. We found no direct correlation between protein concentration and the decrease in virulence gene expression in these samples. Previous observations using the luminescent E. coli LEE1 and LEE2 constructs suggest that false-positive results can be obtained, because of the presence of some components from the culture medium or samples that can alter the luminescence expression (MedellinPeña et al., 2007; Delcenserie et al., 2012; Zeinhom et al., 2012). Therefore, all positive results were further validated by $\mathrm{RT}-\mathrm{qPCR}$.

\section{Effect of Raw and Heat-Treated MFGM on Virulence Expression}

To study the effects of heat-treated and raw MFGM on virulence gene expression, the virulence genes ler, stx2B, luxS, and fliC were monitored in E. coli O157:H7 under exposure to $100 \mu \mathrm{g}$ of heat-treated or raw MFGM using RT-qPCR. The expression of the housekeeping genes gst and gnd was chosen for normalization of the results. All the results were normalized to the geometric average expression of both genes and adjusted accordingly to the efficiency of each pair of primers (Pfaffl, 2001; Vandesompele et al., 2002). The PCR efficiency, $\mathrm{Ct}$ values, and standard deviations are presented in Table 1.

The results were analyzed at early-exponential (4 h) and mid-exponential $(6 \mathrm{~h})$ growth phase because virulence gene expression of $E$. coli $\mathrm{O} 157: \mathrm{H} 7$ is higher during the exponential phase than during the stationary phase (Bergholz et al., 2007). The results failed to confirm the effects observed with the luminescent LEE1 reporter strain because no decrease in ler expression was observed with the heat-treated fraction (ler being 
Table 1. Effect of milk fat globule membrane (MFGM) on expression (cycle threshold values \pm SD) of virulence genes of enterohemorrhagic Escherichia coli $\mathrm{O} 157: \mathrm{H} 7$ after 4 and $6 \mathrm{~h}^{1}$

\begin{tabular}{|c|c|c|c|c|c|c|c|}
\hline Gene & $\begin{array}{c}\text { PCR } \\
\text { efficiency }^{2} \\
(\%)\end{array}$ & \multicolumn{3}{|c|}{$4 \mathrm{~h}$} & \multicolumn{3}{|c|}{$6 \mathrm{~h}$} \\
\hline gnd & 104 & $21.59 \pm 0.16$ & $21.53 \pm 0.17$ & $21.59 \pm 0.15$ & $22.57 \pm 0.97$ & $20.74 \pm 0.23$ & $21.29 \pm 0.29$ \\
\hline ler & 97 & $25.52 \pm 0.37$ & $25.67 \pm 0.51$ & $25.86 \pm 0.40$ & $23.13 \pm 0.23$ & $21.97 \pm 0.27$ & $22.90 \pm 0.25$ \\
\hline stx2B & 113 & $23.27 \pm 0.17$ & $24.40 \pm 0.22$ & $23.74 \pm 0.14$ & $22.30 \pm 0.37$ & $23.06 \pm 0.09$ & $24.01 \pm 0.67$ \\
\hline
\end{tabular}

${ }^{1}$ No treatment $=$ Escherichia coli O157:H7 grown in Luria-Bertani broth (LB) for 4 or 6 h; raw MFGM $=E$. coli O157:H7 grown in LB supplemented with untreated MFGM for 4 or $6 \mathrm{~h}$; heat-treated MFGM $=$ E. coli O157:H7 grown in LB supplemented with heat-treated MFGM for 4 or $6 \mathrm{~h}$.

${ }^{4} \mathrm{PCR}$ efficiency $\mathrm{E}=\left[\left(10^{(-1 / \text { slope })}\right) / 2\right] \times 100 \%$.

the first gene of the LEE1 operon). However, the results observed for the other genes indicated that MFGM did affect expression of virulence genes of $E$. coli $\mathrm{O} 157$.

At $4 \mathrm{~h}$ (Table 1 and Figure 2), the MFGM from heattreated milk did not induce any significant changes in $E$. coli virulence gene expression, whereas that from raw milk produced a significant increase in expression of fliC (ratio $+7.28 ; P \leq 0.001)$ and $\operatorname{luxS}$ (ratio +2.53 ; $P \leq 0.01$ ) and a decrease of stx2B expression (ratio $-2.70 ; P \leq 0.01)$.

At $6 \mathrm{~h}$ of culture (Table 1 and Figure 2), both raw and heat-treated MFGM downregulated expression of stx2B (ratios of -5.96 and -7.69 respectively; $P \leq$ $0.05)$. In addition, heat-treated MFGM caused a significant decrease in fliC expression compared with the raw fraction (ratio of $-9.43 ; P \leq 0.05$ ). The raw fraction was able to induce a slight but significant decrease of luxS gene expression (ratio of $-3.43 ; P \leq 0.05$ ).
Several studies have reported an antimicrobial effect of the xanthine oxidase present in MFGM fractions on E. coli $\mathrm{O} 157: \mathrm{H} 7$ and other gastrointestinal pathogens (Hancock et al., 2002; Martin et al., 2004). This is not, however, the cause of the effects identified in the present study, because heating milk would denature the protein. Sprong et al. (2002) reported that bovine milk fat triglycerides containing C10:0 and C12:0 were able to exert a bactericidal effect against Campylobacter jejuni and L. monocytogenes. The bactericidal effect was weaker, however, on E. coli O157:H7. Sánchez-Juanes et al. (2009) demonstrated that components of MFGM such as glycosphingolipids were able to bind enterotoxigenic E. coli strains and potentially render them unable to colonize the intestine.

Gene expression by $E$. coli in the presence of bovine milk has been studied by Salisbury et al. (1999). They demonstrated that bovine milk was able to inhibit the

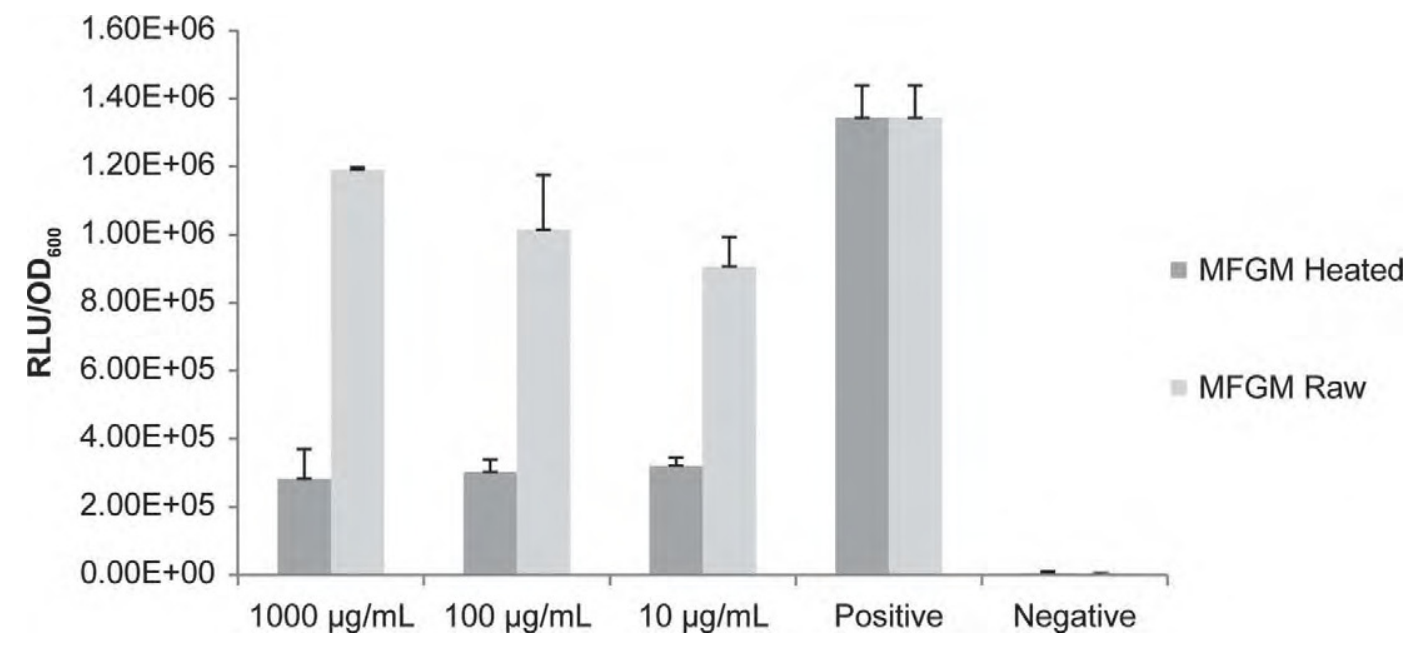

Figure 1. Effect of heated and raw milk fat globule membrane (MFGM) on expression of locus of enterocyte effacement (LEE 1) of Escherichia coli O157:H7. Results were expressed as relative light units (RLU, counts/min) and adjusted to optical density at 600 nm (RLU/ $\left.\mathrm{OD}_{600}\right)$. The data are mean $( \pm \mathrm{SD})$ values of 3 independent replicates of each strain. 


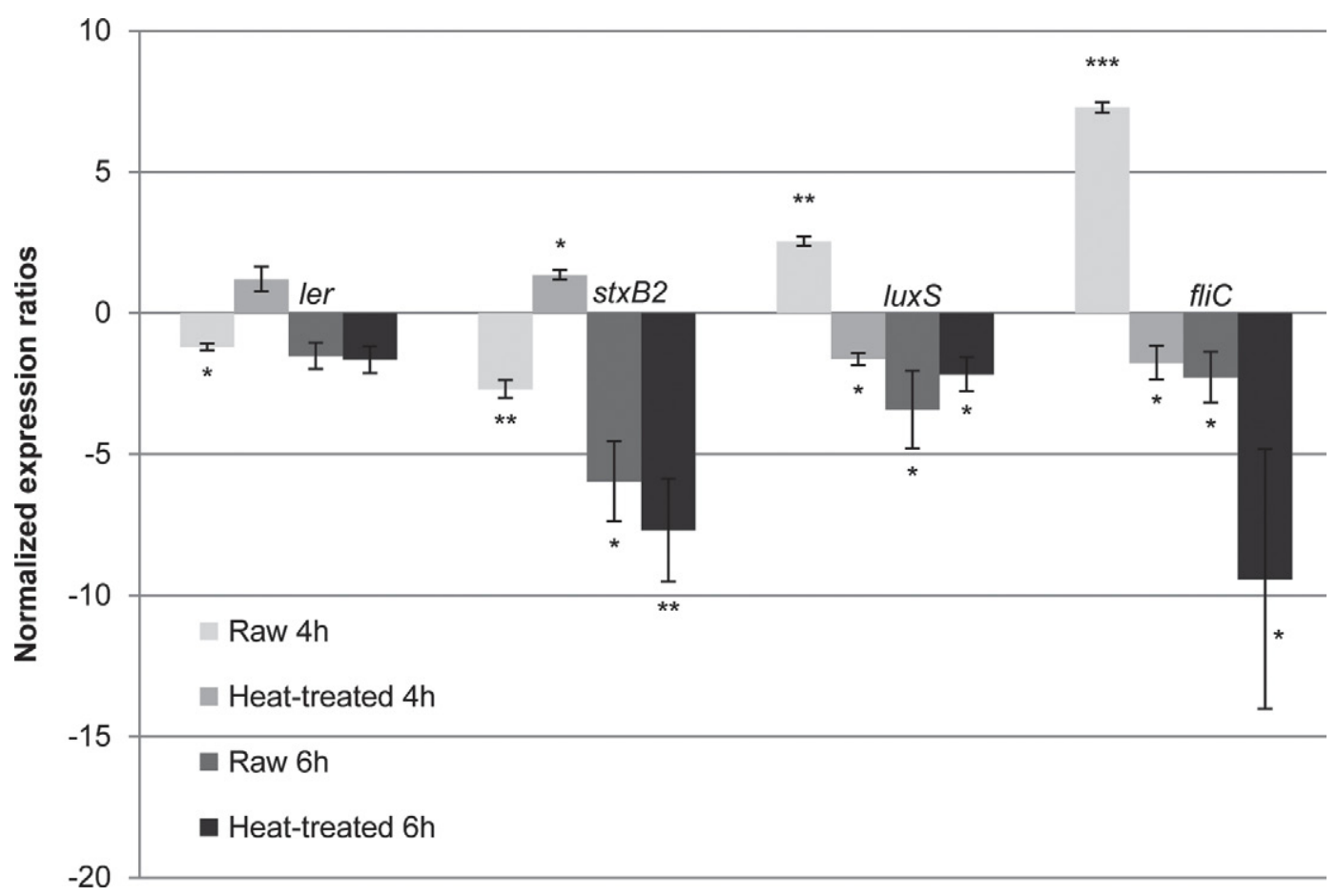

Figure 2. Effect of milk fat globule membrane (MFGM) isolated from heated (at $80^{\circ} \mathrm{C}$ ) and raw milk on the expression of virulence genes of enterohemorrhagic Escherichia coli O157:H7 (EHEC) after 4 and $6 \mathrm{~h}$ of incubation. Expression ratios of the different genes of E. coli O157:H7 ATCC 43894 were normalized to the expression of the regulator genes gnd and gst and compared with those of the no-treatment control. Negative values represent downregulation of the genes in presence of raw or heat-treated MFGM, whereas positive values indicate upregulation. ${ }^{*} P \leq 0.05 ; * * P \leq 0.01 ;{ }^{* * *} P \leq 0.001$.

general metabolic expression of a clinical strain of $E$. coli; however, specific virulence expression was not examined.

To our knowledge, the present study is the first to demonstrate a specific effect of MFGM on expression of Shiga toxin genes and on genes involved in the motility of E. coli O157:H7. Our results show that both heated and raw MFGM exert an effect by decreasing Shiga toxin and fliC expression of E. coli O157:H7. Interestingly, the effect was stronger with heated MFGM. The differences in protein composition could explain the observed differences between the 2 preparations. Further studies should allow identification of the active components present in MFGM. In parallel, in vitro studies could be performed to determine if MFGM or its active components are able to inhibit adhesion of $E$. coli to intestinal cells. Finally, studies on mice or other animal models should be conducted to confirm those results in vivo.

\section{CONCLUSIONS}

The MFGM fractions exerted an inhibitory effect against the expression of Shiga toxin genes by E. coli O157:H7. Interestingly, this effect was more pronounced with heat-treated MFGM fractions, indicating that the effect cannot be attributed to the main protein fractions present in the MFGM. We observed a significant decrease in expression of one gene, $f l i C$, which is involved in the motility of E. coli O157:H7. This work presents, for the first time, evidence of the inhibitory effect of MFGM on the virulence of E. coli O157:H7.

\section{ACKNOWLEDGMENTS}

The authors thank Edita Verespej (University of Guelph, Guelph, ON, Canada) for her kind assistance with the preparation of the samples. Financial support for this project was provided by Dairy Farmers of Ontario (Mississauga, ON, Canada) and the Ontario Dairy Council (Mississauga, ON, Canada) through the Industry research chair program.

\section{REFERENCES}

Bergholz, T. M., L. M. Wick, W. Qi, J. T. Riordan, L. M. Ouellette, and T. S. Whittam. 2007. Global transcriptional response of Escherichia coli $\mathrm{O} 157: \mathrm{H} 7$ to growth transitions in glucose minimal medium. BMC Microbiol. 7:97.

Boerlin, P., S. A. McEwen, F. Boerlin-Petzold, R. P. Johnson, and C. L. Gyles. 1999. Associations between virulence factors of Shiga 
toxin-producing Escherichia coli and disease in humans. J. Clin. Microbiol. 37:497-503.

Corredig, M., and D. G. Dalgleish. 1998. Effect of heating of cream on the properties of milk fat globule membrane isolates. J. Agric. Food Chem. 46:2533-2540.

Corredig, M., R. Roesch, and D. G. Dalgleish. 2003. Production of a novel ingredient from buttermilk. J. Dairy Sci. 86:2744-2750.

Delcenserie, V., G. LaPointe, T. Charaslertrangsi, A. Rabalski, and M. Griffiths. 2012. Glucose decreases virulence gene expression of Escherichia coli O157:H7. J. Food Prot. 75:748-752.

Griffin, P. M., and R. V. Tauxe. 1991. The epidemiology of infections caused by Escherichia coli O157:H7, other enterohemorrhagic E. coli, and the associated hemolytic uremic syndrome. Epidemiol. Rev. 13:60-98.

Hancock, J. T., V. Salisbury, M. C. Ovejero-Boglione, R. Cherry, C. Hoare, R. Eisenthal, and R. Harrison. 2002. Antimicrobial properties of milk: Dependence on presence of xanthine oxidase and nitrite. Antimicrob. Agents Chemother. 46:3308-3310.

Heid, H. W., and T. W. Keenan. 2005. Intracellular origin and secretion of milk fat globules. Eur. J. Cell Biol. 84:245-258.

Kanno, C., Y. Shimomura, and E. Takano. 1991. Physicochemical properties of milk-fat emulsions stabilized with bovine-milk fat globule-membrane. J. Food Sci. 56:1219-1223.

LeBlanc, J. J. 2003. Implication of virulence factors in Escherichia coli O157:H7 pathogenesis. Crit. Rev. Microbiol. 29:277-296.

Lopez, C. 2010. Lipid domains in the milk fat globule membrane: Specific role of sphingomyelin. Lipid Technol. 22:175-178.

Martin, H. M., J. T. Hancock, V. Salisbury, and R. Harrison. 2004. Role of xanthine oxidoreductase as an antimicrobial agent. Infect. Immun. 72:4933-4939.

McClure, P. 2005. Escherichia coli: Virulence, stress response and resistance. Pages 240-278 in Understanding Pathogen Behavior. M. Griffiths, ed. CRC Press LLC, Boca Raton, FL

Medellin-Peña, M. J., H. Wang, R. Johnson, S. Anand, and M. W. Griffiths. 2007. Probiotics affect virulence-related gene expression in Escherichia coli O157:H7. Appl. Environ. Microbiol. 73:42594267 .

Murgiano, L., A. M. Timperio, L. Zolla, S. Bongiorni, A. Valentini, and L. Pariset. 2009. Comparison of milk fat globule membrane (MFGM) proteins of Chianina and Holstein cattle breed milk samples through proteomics methods. Nutrients 1:302-315.

Page, S., D. Powell, M. Benboubetra, C. R. Stevens, D. R. Blake, and F. Selase. 1998. Xanthine oxidoreductase in human mammary epithelial cells: Activation in response to inflammatory cytokines. Biochim. Biophys. Acta 1381:191-202.

Parodi, P. W. 1997. Cows' milk fat components as potential anticarcinogenic agents. J. Nutr. 127:1055-1060.

Paton, J. C., and A. W. Paton. 1998. Pathogenesis and diagnosis of Shiga toxin-producing Escherichia coli infections. Clin. Microbiol. Rev. 11:450-479.

Pfaffl, M. W. 2001. A new mathematical model for relative quantification in real-time RT-PCR. Nucleic Acids Res. 29:e45.

Proulx, F., E. G. Seidman, and D. Karpman. 2001. Pathogenesis of Shiga toxin associated hemolytic uremic syndrome. Pediatr. Res. $50: 163-171$.
Rashid, R. A., T. A. Tabata, M. J. Oatley, T. E. Besser, P. I. Tarr, and S. L. Moseley. 2006. Expression of putative virulence factors of Escherichia coli O157:H7 differs in bovine and human infections. Infect. Immun. 74:4142-4148.

Salisbury, V., A. Pfoest, H. Wiesinger-Mayer, R. Lewis, K. E. Bowker, and A. P. MacGowan. 1999. Use of a clinical Escherichia coli isolate expressing lux genes to study the antimicrobial pharmacodynamics of moxiflaxacin. J. Antimicrob. Chemother. 43:829-832.

Sánchez-Juanes, F., J. M. Alonso, L. Zancada, and P. Hueso. 2009. Glycosphingolipids from bovine milk and milk fat globule membranes: A comparative study. Adhesion to enterotoxigenic Escherichia coli strains. Biol. Chem. 390:31-40.

Sharma, S. K., and D. G. Dalgleish. 1994. Effect of heat-treatments on the incorporation of milk serum-proteins into the fat globulemembrane of homogenized milk. J. Dairy Res. 61:375-384.

Sichien, M., N. Thienpont, E. Frederick, T. T. Le, J. Van Camp, and K. Dewettinck. 2009. Processing means for milk fat fractionation and production of functional compounds. Pages 68-102 in DairyDerived Ingredients. 1st ed. M. Corredig, ed. Woodhead Publishing/CRC Press, New York, NY.

Singh, H. 2006. The milk fat globule membrane-A biophysical system for food applications. Curr. Opin. Colloid Interface Sci. 11:154163

Spitsberg, V. L. 2005. Invited review: Bovine milk fat globule membrane as a potential nutraceutical. J. Dairy Sci. 88:2289-2294.

Sprong, R. C., M. F. E. Hulstein, and R. van der Meer. 2002. Bovine milk fat components inhibit food-borne pathogens. Int. Dairy J. 12:209-215.

Vandesompele, J., K. De Preter, F. Pattyn, B. Poppe, N. Van Roy, A. De Paepe, and F. Speleman. 2002. Accurate normalization of real-time quantitative RT-PCR data by geometric averaging of multiple internal control genes. Genome Biol. 3:H0034.

Vissac, C., D. Lemery, L. Le Corre, P. Fustier, P. Dechelotte, J. C. Maurizis, Y. G. Bignon, and D. J. Bernard-Gallon. 2002. Presence of BRCA1 and BRCA2 proteins in human fat globules after delivery. Biochim. Biophys. Acta 1586:50-56

Wang, X., R. Hirmo, R. Willen, and T. Wadstrom. 2001. Inhibition of Helicobacter pylori infection by bovine milk glycoconjugates in Balb/cA mouse model. J. Med. Microbiol. 50:430-435.

Wen, S. X., L. D. Teel, N. A. Judge, and A. D. O'Brien. 2006. A plant-based oral vaccine to protect against systemic intoxication by Shiga toxin type 2. Proc. Natl. Acad. Sci. USA 103:7082-7087.

Ye, A., H. Singh, M. W. Taylor, and S. Anema. 2002. Characterization of protein components of natural and heat-treated milk fat globule membranes. Int. Dairy J. 12:393-402.

Zeinhom, M., A. M. Tellez, V. Delcenserie, A. M. El-Kholy, S. H. ElShinawy, and M. W. Griffiths. 2012. Yoghurt containing bioactive molecules produced by Lactobacillus acidophilus La-5 exerts a protective effect against enterohaemorrhagic Escherichia coli (EHEC) in mice. J. Food Prot. In press. 